\title{
Evaluation of selected plant extracts for in vitro anti-marine leech (Zeylanicobdella arugamensis) activity
}

\author{
Wan Norhana, M.N. ${ }^{1}$, Kua, B.C. ${ }^{2 *}$, Liyana, R. $^{1}$ \\ ${ }^{1}$ Fisheries Research Institute, 11960 Batu Maung, Penang, Malaysia \\ ${ }^{2}$ National Fish Health Research Division, Fisheries Research Institute, 11960 Batu Maung, Penang, Malaysia \\ *Corresponding author: kuaben01@dof.gov.my
}

\section{ARTICLE HISTORY}

Received: 11 April 2020

Revised: 21 October 2020

Accepted: 22 October 2020

Published: 25 March 2021

\begin{abstract}
The aqueous extracts of thirty-four (34) tropical plants were tested in vitro for potential antimarine leech (Zeylanicobdella arugamensis) activity. The anti-leech activity was determined by exposing 8 adult leeches ( $Z$. arugamensis) $(9.3 \pm 1.5 \mathrm{~mm}$, aged 15 days) to $20 \mu \mathrm{l}$ of plant extract $(0.5 \mathrm{~g} / \mathrm{ml})$ for $5 \mathrm{~min}$ in a 24-well plate. After $5 \mathrm{~min}$ of exposure, the leeches were rinsed and transferred into seawater, to enable them to revive from the effect of the extract. Leech movements were observed from time to time and the numbers of paralyzed or dead leeches were recorded at 5, 20, 30 and $240 \mathrm{~min}$. The efficacy of the plant extract in killing the adult $Z$. arugamensis during the 5 min exposure is reflected on the anti-leech property of the extract. The anti-leech property of positive plant extracts was also determined at different exposure time $(1,3,5 \mathrm{~min})$ and dilutions $(1 / 2(0.25 \mathrm{~g} / \mathrm{ml}), 1 / 5(0.1 \mathrm{~g} / \mathrm{ml})$ and $1 / 10(0.05 \mathrm{~g} / \mathrm{ml})$. The extracts of 4 plants (Melastoma malabathricum, Piper betle, Tetracera indica and Etlingera coccinea) demonstrated anti-leech activity. The effects of $M$. malabathricum, $P$. betle and $E$. coccinea extracts on the leeches were very rapid causing death as early as a few seconds upon exposure. However, all four positive plant extracts were found not effective in killing the leeches at $1 / 10$ dilution $(0.05 \mathrm{~g} / \mathrm{ml})$. A Scanning Electron Microscopy examination on leeches exposed to the positive plant extracts exhibited effects such as protruding proboscis and shrunken or swollen bodies.
\end{abstract}

Keywords: Anti-parasite; Aqueous extracts; in vitro; Tropical plant; Marine leech; Zeylanicobdella arugamensis.

\section{INTRODUCTION}

The marine leech (Zeylanicobdella arugamensis) had been reported to infest some brackish water and marine fishes in Sri Lanka, Malay Peninsula and India (De Silva, 1963; De Silva \& Fernando, 1965; Raj et al., 1977). This leech had also been reported to be commonly found in Indonesia and along the coast of Queensland, Australia (Burreson, 1995). An extremely heavy infestation of $Z$. arugamensis and mortality within 3 days had also been reported in tank-reared juvenile and adult orange-spotted grouper, Epinephelus coioides Hamilton at SEAFDEC Aquaculture Department in Iloilo, Philippines (Cruz-Lacierda et al., 2000).

The prevalence of $Z$. arugamensis in Malaysia has been increasing all these years. Previously, Leong and Wong (1988) highlighted a very small percentage $(0.4 \%)$ of an unidentified marine leech infestation in their comparative study of the parasite fauna in the wild and cultured grouper (Epinephelus malabaricus). Kua et al. (2006) had also reported a $100 \%$ prevalence of $Z$. arugamensis infestation in sea bass fingerlings reared in cages at Bukit Tambun, Penang, Malaysia which resulted in about $60 \%$ mortality after 2 weeks of stocking. Similarly, $100 \%$ prevalence with a mean intensity of 35 marine leeches per fish (based on the average body weight of $292.3 \pm 62.4 \mathrm{~g}$ ) was observed in tiger grouper Epinephelus fuscoguttatus. Apart from this, several studies on the occurrences of $Z$. arugamensis in Malaysia had been highlighted on the cultured Asian sea bass (Lates calcarifer (Bloch)), crimson snapper (Lutjanus erythropterus) and hybrid groupers of (Epinephelus fuscoguttatus $\times$ E. lanceolatus) (Kua et al., 2014; Ravi \& Yahaya 2017; Shah et al., 2020).

Generally, control measures used for marine leech at fish cages in Bukit Tambun, Penang are either by manually picking the leeches from the infested fish or to dip the fish in freshwater bath or 50-100 ppm formalin bath for $1 \mathrm{~h}$ (Lacierda et al., 2000; Kua et al., 2014; Shah et al., 2020). The use of the freshwater to control the parasite in tanks may be effective but has limited applications. Reinfection may occur as 25 to $33 \%$ of adult and 17 to $50 \%$ of the juvenile marine leeches are able to re-infect the fish after freshwater bath (Kua et al., 2019). In addition, if the leeches had deposited cocoons in the culture facilities, total elimination of the parasites may be difficult because cocoons are very resistant to chemical treatment. 
There are quite a number of reports on anti-leech effect from plants extracts. Zingiber officinale, Nicotiana tabacum (tobbaco), Satureja khuzistanica (jamzad), Allium sativum (garlic) olive, Vitis vinifera (grape vine), Artemisia sp. (afsintin) and Matricaria chamomilla (chamomile) had been demonstrated to possess anti-leech effect against the aquatic leech, Limnotis nilotica (Forouzan et al., 2012; Bahmani \& RafieianKopaei, 2014). Shah et al. (2020) recently reported on the anti-parasitic activity using methanol extract of the local medicinal plant Dillenia suffruticosa (or local Malay name, 'Simpoh air' or 'Simpoh ayer') specifically against the marine leech, Z. arugamensis. Since there is still a dearth of information on the anti-marine leech activity of plant extracts, this study was carried out with the main objective of determining the anti-marine leech activity of aqueous plant extracts including those from underutilized species for potential use in the aquarium, marine hatcheries and mariculture industry in general.

\section{MATERIALS AND METHODS}

\section{Preparation of aqueous plant extract}

A total of thirty-four (34) plant materials (Table 1) were collected from Penang, Kedah, Kelantan and Terengganu, Malaysia. Some of the plants were of commercial value while the rest are considered underutilized. Plants such as Nicotina tabacum, Cassia javanica spp. nodosa and Entada spiralis, Piper Betle were chosen based on the local uses to keep off parasites such as the freshwater leech (Hirudinea). The plants used in this study were collected from the wild, agropark or home garden (Table 1). The identification of these plants was confirmed with the plant taxonomist from the Forest Research Institute, Kepong, Malaysia. Dried specimens of the leaves were deposited in the laboratory.

The leaves of the plant were washed with distilled water, pat dried with a clean towel and left to dry at an ambient room temperature $\left(28^{\circ} \mathrm{C}\right)$ for a day. The leaves were cut into small pieces and dried in an oven $\left(50^{\circ} \mathrm{C}\right)$ thereafter until they became brittle. Dried leaves were powdered using a metal grinder (Waring, USA). The powders were preserved in clean plastic containers, kept away from light, heat and moisture until use. About $5 \mathrm{~g}$ of dried plant powder was soaked in $50 \mathrm{ml}$ distilled water which was left at room temperature for $24 \mathrm{~h}$ and filtered through a filter paper (Whatmann Ltd.). The filtrate was then concentrated using a rotary evaporator (Buchi R-114 Rotary Vap System, Switzerland) at reduced temperature and pressure (Pandey \& Tripathy, 2014). The evaporated plant extracts were thick and viscous. Each extract was pipetted out into dark glass vials and stored in a refrigerator for use when required. For standardisation

Table 1. The list of plants used in this study

\begin{tabular}{|c|c|c|c|c|c|}
\hline Scientific name & Common name & Local name & Family & Part used & Sources \\
\hline Melastoma malabathricum & Straits Rhododendron & Senduduk & Melastomaceae & Leaves & Kg. Pisang, Kedah \\
\hline Strobilanthes crispus & - & $\begin{array}{l}\text { Pecah beling / } \\
\text { Batu jin }\end{array}$ & Acanthaceae & Leaves & Kg. Bachok, Kelantan \\
\hline Thespesia populnea & Portia Tree & Bebaru & Malvaceae & Leaves & Pantai Jerejak, Penang \\
\hline Tetracera indica & Sandpaper vine & Mempelas & Dilleniaceae & Leaves & Kg. Setiu, Terengganu \\
\hline Passiflora edulis & Passion fruit & Markisah & Passifloraceae & Leaves & Kg. Bachok, Kelantan \\
\hline Artocarpus altilis & Breadfruit & Sukun & Moraceae & Leaves & Bukit Mertajam, Penang \\
\hline Cassia alata & $\begin{array}{l}\text { Candelabra bush, } \\
\text { ringworm }\end{array}$ & Gelenggang & Leguminosae & Leaves & Kg. Pulau Sayak, Kedah \\
\hline Piper sarmentosum & Wild betel & Kaduk & Piperaceae & Leaves & Bukit Mertajam, Penang \\
\hline Barringgtonia spp. & Cutnut & Putat & Lecythidaceae & Leaves & Bukit Mertajam, Penang \\
\hline Psidium guajaya & Guava & Jambu batu & Myrtaceae & Leaves & Bukit Mertajam, Penang \\
\hline Ricinus communis & Castor oil & Jarak pagar & Euphorbiaceae & Leaves & Kg. Pisang, Kedah \\
\hline Morinda citrifolia & Cheese fruit & Noni & Rubiaceae & Leaves & Bukit Mertajam, Penang \\
\hline Terminalia catappa & Indian almond & Ketapang & Combretaceae & Leaves & Batu Maung, Penang \\
\hline Piper betle & Betel leaf & Sireh & Piperaceae & Leaves & Bayan Baru, Penang \\
\hline Nicotiana tabacum & Tobacco & Tembakau & Solanaceae & Leaves & Kg. Bachok, Kelantan \\
\hline Dieffenbachia seguine & Dumb cane & Keladi tikus & Araceae & Leaves & Bukit Mertajam, Penang \\
\hline Tacca cristata & White bat plant & Belimbing tanah & Taccaceae & Leaves & Setiu AgroPark, Terengganu \\
\hline Cassia javanica ssp. nodosa & Apple-blossom & Busuk & Leguminosae & Leaves & Pantai Semarak, Terengganu \\
\hline Clinacanthus nutans & Sabahsnake grass & Belalai gajah & Acanthaceae & Leaves & Kg. Setiu, Terengganu \\
\hline Vitex trifolia & Simple leaf chastetree & Lemuni & Lamiaceae & Leaves & Bukit Mertajam, Penang \\
\hline Vernonia amygdalina & Bitterleaf, Vernonia & Afrika & Asteraceae & Leaves & Bukit Mertajam, Penang \\
\hline Streblus asper & $\begin{array}{l}\text { Siamese rough bush, } \\
\text { khoi }\end{array}$ & Kesinai & Moraceae & Leaves & Kg. Pisang, Kedah \\
\hline Entada spiralis & - & Sintuk & Leguminosae & Bark & Sundry shop, Batu Maung \\
\hline Anonna squamosa & Sugar apple & Nona & Annonaceae & Leaves & Gelugor, Penang \\
\hline Rhizopora mucronata & - & Bakau kurap & Rhizophoraceae & Leaves & Batu Maung, Penang \\
\hline Etlingera coccinea & - & Tepus kesing & Zingiberacea & Leaves & Setiu AgroPark, Terengganu \\
\hline Chromolaena odorata & $\begin{array}{l}\text { Siam Weed, } \\
\text { Christmas Bush }\end{array}$ & Kapal terbang & Asteraceae & Leaves & Batu Maung, Penang \\
\hline Garcinia mangostana L. & Mangosteen & Manggis & Clusiaceae & Leaves & Bukit Mertajam, Penang \\
\hline Acalypha indica & Indian copperleaf & Kucing galak & Euphorbiaceae & Leaves & Kg. Pulau Sayak, Kedah \\
\hline Syzygium polyanthum & Indonesian bay leaf & Serai kayu & Myrtaceae & Leaves & Kg. Bachok, Kelantan \\
\hline Pandanus odoratissimus & Screwpine & Mengkuang laut & Pandanaceae & Leaves & Pantai Penarik, Terengganu \\
\hline Vitex pinnata & - & Halban & Verbenaceae & Leaves & Kg. Setiu, Terengganu \\
\hline Rhizophora apiculata & - & Bakau minyak & Rhizophoraceae & Leaves & Batu Maung, Penang \\
\hline Donax grandis & Common donax & Bemban & Marantaceae & Leaves & Kg. Pisang, Kedah \\
\hline
\end{tabular}


purpose, the concentrations of all plant extracts were set at approximately $0.5 \mathrm{~g} / \mathrm{ml}$.

\section{Source and preparation of leech}

The adult leeches ( $Z$. arugamensis) were obtained from infected fish from cages in Bukit Tambun, Penang, Malaysia. Adult leeches were isolated manually and placed into a glass container with $300 \mathrm{ml}$ seawater before being transported to the parasitology laboratory at the National Fish Health (NAFisH) Research Division, Fisheries Research Institute, Batu Maung, Penang, Malaysia. In order to obtain uniformity in terms of size and age of the leech, propagation of marine leech was conducted under laboratory conditions based on method established by Kua et al. (2010). Briefly, the active adult leeches were chosen and placed in filtered seawater at $28 \mathrm{ppt}$ salinity and incubated at $27^{\circ} \mathrm{C}$. After 24 hours, the adult leeches were removed and the cocoons laid were further incubated for 6 days. The juvenile leeches hatched out from the cocoons on day 6 and were subsequently fed with fish blood. The juvenile leeches were fed daily for 9 days and they attained adult stage and were ready for use in the experiment. The leeches were put in small aquarium tanks $(15 \mathrm{~cm} \times 20 \mathrm{~cm})$ with live fish to feed on.

Microscopic examination of the live leeches exhibited an elongated and cylindrical body (average length of $9.3 \pm 1.5$ $\mathrm{mm}$ ), brownish-black in colour and narrowing at both ends with oral and caudal suckers. These two suckers were extensively used for movement. The normal behaviour of healthy leeches involved vigorous swimming in water and constantly finding substrates to attach to. They would use the caudal sucker at the posterior of the body to anchor to the substrate and then stretch their body and attach again using the smaller oral sucker at the anterior end of the body. The caudal sucker then detached, bounced forward and reattached near the fixed oral sucker, which was then freed. These steps were repeated swiftly and systematically.

\section{Anti-leech assay}

The method used in this study was developed in-house at the laboratory in NAFisH. Briefly, adult marine leech about 15 days old were picked from the side of the aquarium tank using a glass rod and quickly placed on the base of the well of a flat-bottom cell culture plate (24-wells). Volumes of 20 $\mu \mathrm{l}$ of crude plant extract (app. $0.5 \mathrm{~g} / \mathrm{ml}$ ) were directly spotted on the leeches $(n=32)$ and left for $5 \mathrm{~min}$. The effects of the extract on the leech motility were closely observed under a stereomicroscope (40X) and recorded. After 5 min exposure to the plant extract, the leech was taken out from the well, rinsed with seawater and transferred to an adjacent well containing $1.5 \mathrm{ml}$ of clean seawater to enable the leech to recover from the effect of the extract. The mobility and behaviour of the leech were closely observed under a stereomicroscope (40X) at 5, 20, 30 and 240 min intervals (Kua et al., 2000). The evaluation of the death of a leech was based on immobility of the leech after 3-5 times stimulation with a needle and time of death was recorded using the stopwatch. The numbers of dead leeches were counted and recorded according to time of death i.e. $\leq 5 \mathrm{~min}, \leq 20 \mathrm{~min}, \leq 30$ $\mathrm{min},<240 \mathrm{~min}$. The numbers of survived leeches were also recorded. For each plant extract, the treatments were performed on 8 individuals $(n=8)$ in four replicates $(N=32)$. In this study, the plant extract which killed Z. arugamensis immediately or after stipulated times was considered as having anti-leech properties. For the negative control, $20 \mu \mathrm{l}$ of distilled water was spotted on the different sets of leeches while for the positive control, $20 \mu \mathrm{l}$ of $100 \mathrm{ppm}$ formalin solution was used on another set of leeches.
The initial concentration of all plant extracts used in the experiment was set at $0.5 \mathrm{~g} / \mathrm{ml}$. For plant extracts with positive anti-leech property, $1 / 2(0.25 \mathrm{~g} / \mathrm{ml}), 1 / 5(0.1 \mathrm{~g} / \mathrm{ml})$ and $1 / 10(0.05 \mathrm{~g} / \mathrm{ml})$ dilutions were prepared by diluting the original extract with distilled water to determine the minimal concentration needed to kill the leech. The anti-leech assay was repeated as described above. Anti-leech activity was also carried out at different exposure time ( $1 \mathrm{~min}$ and $3 \mathrm{~min}$ ) for positive plant extract. For each treatment, the measurements were performed on five individuals $(n=5)$ in triplicates $(\mathrm{N}=15)$.

\section{Observation of marine leech morphology under Scanning Electron Microscopy (SEM)}

There were not much morphological differences on the leeches treated with positive plant extracts when observed under the stereomicroscope. The most noticeable features of the dead leeches were hardened and shrunken bodies. To examine further, the dead marine leeches were fixed in McDowell-Trump fixative. The specimens were washed in $0.1 \mathrm{M}$ Phosphate buffer $(\mathrm{pH} \mathrm{7.2)}$ for $10 \mathrm{~min}$ and post-fixed in $1 \%$ aqueous osmium tetroxide for $1-2 \mathrm{hr}$ (McDowell \& Trump, 1976). Subsequently, the specimens were dehydrated in graded ethanol, treated with hexamethydisilazane (HMDS) for $10 \mathrm{~min}$ and air-dried at room temperature. The dried samples were mounted onto a SEM specimen stub using a double-sided sticky tape and the samples were coated with gold before viewing under Leo Supra 50VP Field Emission SEM equipped with Oxford INCA 400 energy dispersive $x$-ray microanalysis system at magnifications of $25 \mathrm{X}-10.0 \mathrm{KX}$.

\section{RESULTS AND DISCUSSION}

There is no specific guideline to evaluate the efficacy of plant anti-leech activity to date. Since mobility constitutes a relatively reliable indicator of viability, therefore in this study, immobility or death was used as a measure of anti-leech activity of plant extracts. Table 2 presents various degrees of activity of thirty-four plants extracts on adult marine leeches ( $Z$. arugamensis). The extracts of 4 out of the $34(12 \%)$ tropical plants investigated in this study demonstrated anti-leech activity. The four plants were Melastoma malabathricum (Straits Rhododendron), Tetracera indica (Sandpaper vine), Piper betle (betel) and Etlingera coccinea (perennial gingers). The effects of these plant extracts on leeches were severe causing death almost immediately after exposure. Upon exposure to these extracts, the leeches were immediately paralysed, body became hardened, shrunk and appeared darker in colour. On the other hand, a total of $10(29 \%)$ plant extracts paralyzed the leeches for a while ( $\leq 5 \mathrm{~min})$. A total of $5(15 \%)$ plant extracts (Piper sarmentosum, Barringtonia spp., Psidium guajaya, Garcinia mangostana, Entada spiralis) paralyzed the leeches for a longer period $(\leq 20 \mathrm{~min})$. Fourteen plant extracts $(41 \%)$ did not have any effect on the leeches as they were still seen active even after 4 hrs. Those treated with formalin (100 ppm) were paralysed upon exposure, but after being transferred into seawater they turned active again. Mobility of the leeches treated with distilled water were not affected at all and they remained active.

Tables 3 and 4 show the effects of four plant extracts on Z. arugamensis at different exposure time and concentrations, respectively. The effect of $M$. malabathricum and $P$. betle extracts on the leeches was very rapid causing $100 \%$ mortality of the leeches as early as $1 \mathrm{~min}$ exposure. Extracts of $T$. indica and $E$. coccinea only caused $80 \%$ and $60 \%$ mortality of the leeches, respectively after $1 \mathrm{~min}$ exposure. $M$. malabathricum extracts 
Table 2. Effects of thirty-four aqueous plants extracts on adult marine leech (Z. arugamensis) after 5 minutes' exposure expressed as a percentage of immobile leeches compared to the total number of leeches in the wells after to plant extract.

\begin{tabular}{|c|c|c|c|c|c|}
\hline & \multirow{2}{*}{ Scientific names } & \multicolumn{4}{|c|}{$\begin{array}{l}\text { Percentage (\%) of immobile leeches compared to the total number } \\
\text { of leeches in the wells after treatment with plant extracts }\end{array}$} \\
\hline & & $\leq 5 \min$ & $\leq 20 \min$ & $\leq 30 \mathrm{~min}$ & $240 \mathrm{~min}$ \\
\hline 1. & Melastoma malabathricum & 100 & 100 & 100 & 100 \\
\hline 2. & Strobilanthes crispus & 0 & 0 & 0 & 0 \\
\hline 3. & Thespesia populnea & 100 & 0 & 0 & 0 \\
\hline 4. & Tetracera indica & 100 & 100 & 100 & 100 \\
\hline 5. & Passiflora edulis & 100 & 0 & 0 & 0 \\
\hline 6. & Artocarpus altilis & 0 & 0 & 0 & 0 \\
\hline 7. & Cassia alata & 100 & 0 & 0 & 0 \\
\hline 8. & Piper sarmentosum & 100 & 100 & 0 & 0 \\
\hline 9. & Barringgtonia spp. & 100 & 100 & 0 & 0 \\
\hline 10. & Psidium guajaya & 100 & 100 & 12.5 & 0 \\
\hline 11. & Ricinus communis & 100 & 0 & 0 & 0 \\
\hline 12. & Morinda citrifolia & 100 & 0 & 0 & 0 \\
\hline 13. & Terminalia catappa & 0 & 0 & 0 & 0 \\
\hline 14. & Piper betle & 100 & 100 & 100 & 100 \\
\hline 15. & Nicotiana tabacum & 100 & 100 & 0 & 0 \\
\hline 16. & Dieffenbachia seguine & 100 & 0 & 0 & 0 \\
\hline 17. & Tacca cristata & 0 & 0 & 0 & 0 \\
\hline 18. & Cassia javanica ssp. nodosa & 100 & 0 & 0 & 0 \\
\hline 19. & Clinacanthus nutans & 0 & 0 & 0 & 0 \\
\hline 20. & Vitex trifolia & 0 & 0 & 0 & 0 \\
\hline 21. & Vernonia amygdalina & 100 & 0 & 0 & 0 \\
\hline 22. & Streblus asper & 0 & 0 & 0 & 0 \\
\hline 23. & Entada spiralis & 100 & 75 & 75 & 25 \\
\hline 24. & Anonna squamosal & 0 & 0 & 0 & 0 \\
\hline 25. & Rhizopora mucronata & 0 & 0 & 0 & 0 \\
\hline 26. & Etlingera coccinea & 100 & 100 & 100 & 100 \\
\hline 27. & Chromolaena odorata & 0 & 0 & 0 & 0 \\
\hline 28. & Garcinia mangostana & 100 & 100 & 0 & 0 \\
\hline 29. & Acalypha indica & 100 & 0 & 0 & 0 \\
\hline 30. & Syzygium polyanthum & 100 & 0 & 0 & 0 \\
\hline 31. & Pandanus odoratissimus & 0 & 0 & 0 & 0 \\
\hline 32. & Vitex pinnata & 0 & 0 & 0 & 0 \\
\hline 33. & Rhizophora apiculata & 0 & 0 & 0 & 0 \\
\hline 34. & Donax grandis & 0 & 0 & 0 & 0 \\
\hline 35. & Distilled water & 0 & 0 & 0 & 0 \\
\hline 36. & Formalin (100 ppm) & 0 & 0 & 0 & 0 \\
\hline
\end{tabular}

Table 3. Effects of four plant extracts on adult marine leech (Z. arugamensis) at different exposure time expressed as a percentage of immobile leeches compared to the total number of leeches in the wells during 4 hours' observation

\begin{tabular}{|c|c|c|c|c|c|}
\hline \multirow[t]{2}{*}{ Plant extracts $(0.5 \mathrm{mg} / \mathrm{ml})$} & \multirow[t]{2}{*}{ Exposure time (min) } & \multicolumn{4}{|c|}{$\begin{array}{l}\text { Percentage (\%) of immobile leeches compared to the total number } \\
\text { of leeches in the wells during } 240 \text { min observation }\end{array}$} \\
\hline & & $\leq 5 \min$ & $\leq 20 \min$ & $\leq 30 \min$ & $240 \mathrm{~min}$ \\
\hline \multirow[t]{3}{*}{ Melastoma malabathricum } & 1 & 100 & 100 & 100 & 100 \\
\hline & 3 & 100 & 100 & 100 & 100 \\
\hline & 5 & 100 & 100 & 100 & 100 \\
\hline \multirow[t]{3}{*}{ Tetracera indica } & 1 & 100 & 90 & 80 & 80 \\
\hline & 3 & 100 & 100 & 100 & 100 \\
\hline & 5 & 100 & 100 & 100 & 100 \\
\hline \multirow[t]{3}{*}{ Piper betle } & 1 & 100 & 100 & 100 & 100 \\
\hline & 3 & 100 & 100 & 100 & 100 \\
\hline & 5 & 100 & 100 & 100 & 100 \\
\hline \multirow[t]{3}{*}{ Etlingera coccinea } & 1 & 100 & 100 & 100 & 60 \\
\hline & 3 & 100 & 100 & 100 & 100 \\
\hline & 5 & 100 & 100 & 100 & 100 \\
\hline
\end{tabular}


Table 4. Effects different dilution/concentration of four plant extracts on adult marine leech (Z. arugamensis) after 5 minutes exposure expressed as a percentage of immobile leeches compared to the total number of leeches in the wells during 240 min observation

\begin{tabular}{|c|c|c|c|c|c|}
\hline \multirow[t]{2}{*}{ Plant extract } & \multirow[t]{2}{*}{ Conc. (g/ml) } & \multicolumn{4}{|c|}{$\begin{array}{l}\text { Percentage (\%) of immobile leeches compared to the total number } \\
\text { of leeches in the wells during } 240 \text { min observation }\end{array}$} \\
\hline & & $\leq 5 \min$ & $\leq 20 \min$ & $\leq 30 \mathrm{~min}$ & $240 \mathrm{~min}$ \\
\hline \multirow[t]{3}{*}{ Melastoma malabathricum } & $1 / 2(0.25)$ & 100 & 100 & 100 & 100 \\
\hline & $1 / 5(0.1)$ & 60 & 40 & 30 & 30 \\
\hline & $1 / 10(0.05)$ & 10 & 0 & 0 & 0 \\
\hline \multirow[t]{3}{*}{ Tetracera indica } & $1 / 2(0.25)$ & 100 & 100 & 90 & 80 \\
\hline & $1 / 5(0.1)$ & 30 & 10 & 10 & 10 \\
\hline & $1 / 10(0.05)$ & 0 & 0 & 0 & 0 \\
\hline \multirow[t]{3}{*}{ Piper betle } & $1 / 2(0.25)$ & 100 & 90 & 90 & 80 \\
\hline & $1 / 5(0.1)$ & 70 & 30 & 10 & 10 \\
\hline & $1 / 10(0.05)$ & 30 & 0 & 0 & 0 \\
\hline \multirow[t]{3}{*}{ Etlingera coccinea } & $1 / 2(0.25)$ & 90 & 50 & 50 & 50 \\
\hline & $1 / 5(0.1)$ & 20 & 10 & 0 & 0 \\
\hline & $1 / 10(0.05)$ & 0 & 0 & 0 & 0 \\
\hline
\end{tabular}

Table 5. Reported phytochemical constituent of four plants associated with anti-parasitic activity

\begin{tabular}{|c|c|c|}
\hline Plant & Active compounds & References \\
\hline Melastoma malabathricum & Flavanoids, triterpins, tannins, saponins and steroids & $\begin{array}{l}\text { Zakaria et al. (2006); } \\
\text { Simanjuntak (2008); } \\
\text { Joffry et al. (2012) }\end{array}$ \\
\hline Tetracera indica & $\begin{array}{l}\text { Saponin } \\
\text { Terpenoid, flavonoid, mixture of glycosides and betulinic acid }\end{array}$ & $\begin{array}{l}\text { Rahmani et al. (1985) } \\
\text { Dogarai (2011) }\end{array}$ \\
\hline Piper betle & Alkaloids, carbohydrate, amino acids, tannins and steroidal components & Sugumaran (2011) \\
\hline Etlingera coccinea & Borneol (28.5\%), Camphor (3.8\%), $\beta$-Bisabolene (18.0\%), Lauryl acetate (5.9\%) & Charles et al. (2012). \\
\hline
\end{tabular}

were still effective at $1 / 2(0.25 \mathrm{~g} / \mathrm{ml})$ dilution killing $100 \%$ of the tested leeches while at $1 / 5(0.10 \mathrm{~g} / \mathrm{ml})$ dilution only killed $30 \%$ leeches. At $1 / 2$ dilutions, $T$. indica and $P$. betle extracts managed to kill $80 \%$ of the leeches while E. coccinea only killed $50 \%$ of the leeches. All the 4 positive plant extracts were not effective in killing the leeches at 1/10 $(0.05 \mathrm{~g} / \mathrm{ml})$ dilution.

Table 5 lists the phytochemical compound of the leaves of the four plants with anti-leech activity reported from previous work. Although the four plants belong to four different botanical families (Melastomaceae, Dilleniaceae, Piperaceae, and Zingiberacea), their biochemical compositions have some common components such as tannin and saponin. The presence of tannin has been established in the representative of three ( $M$. malabathricum, $T$. indica and $P$. betle) out of the four plants with anti-leech activity in our study. Tannins are known to produce anti-helminthic activity by binding with the glycoprotein on the cuticle of the parasite which results in mortality (Patel et al., 2010). It also hinders energy production in helminthic parasites by uncoupling oxidative phosphorylation, which could also cause mortality (Danquah et al., 2012). On the other hand, the biological activity of saponin was related to their membrane permeabilizing property and pore formation. Although our study was not designed to specifically evaluate these polyphenolic compounds, the anti-leech activity observed here could be strongly related to the presence of tannin and saponin.
M. malabathricum, T. indica, P. betle, and E. coccinea aqueous extracts had been reported to possess antiparasitic activities in general. For example, other species in Zingiberaceae family, Zingiber officinale (ginger) had been demonstrated to express anti-freshwater leech, Limnatis nilotica (Bahmani et al., 2013). In addition, P. betle had been proven to affect earthworms (Ali \& Mehta, 1970; Evas et al., 1994), tapeworms and hookworms (Garg \& Jain, 1992). Other studies by Suteky and Dwatmadji (2011) and Basripuri et al. (2013) reported on the anti-helminthic properties of $M$. malabatrichum under laboratory conditions. To our knowledge, this is the first report of anti-marine leech activities of $M$. malabathricum, $T$. indica, $P$. betle, and E. coccinea aqueous extracts.

In the current study, we also examined the anti-marine leech activity of Nicotina tabacum, Cassia javanica spp. nodosa and E. spiralis extracts. These plants are known as remedies for treating worms, parasites and leech (Hirudineae) in local traditional medicine. In addition, there was also a report on the anti-leech activity of $N$. tabacum ethanolic extract $(600$ $\mu \mathrm{g} / \mathrm{ml}$ ) against Limnatis nilotica, killing them in about $17 \mathrm{~min}$ after exposure (Bahmani et al., 2010). However, our results indicated that $N$. tabacum, C. javanica and E. spiralis were not effective against marine leech. $C$. javanica aqueous extract did not have any effect on marine leeches. Although the aqueous extract of $N$. tabacum paralyzed the leeches for a short duration $(\leq 20 \mathrm{~min}$ ), but did not kill them. After $5 \mathrm{~min}$ exposure, E. spiralis extract managed to paralyze $75 \%$ for $\leq 30$ 
min and kill $25 \%$ of the leeches. Formalin (100 ppm) and $100 \%$ freshwater failed to paralyze or kill the leeches. This could be due to the short time of exposure of only $5 \mathrm{~min}$. Exposure to $100 \%$ freshwater and $50-200$ ppm formalin for 1 $\mathrm{hr}$ had been shown to kill Z. arugamensis (Cruz-Lacierda et al., 2000).

When the post-exposed leeches were studied under the SEM, it became apparent that the bodies were shrunken or swollen as compared to the original cylindrical shape of untreated marine leech (Figure 1a). Marine leeches treated with E. coccinea (Figure $1 \mathrm{~b}$ ) and $T$. indica (Figure 1c) extract showed shrunken bodies compared to those treated with
$P$. betle which exhibited swollen body (Figure 1d). $M$. malabathricum treated leech (Figure 1e) appeared almost similar to the untreated or the control marine leech. In addition, dead leeches from the $T$. indica and $M$. malabathricum treatment also demonstrated the protruding of proboscis at the anterior sucker. Under normal conditions, the proboscis will protrude when the leech is about to suck the blood from their host. The protruded proboscis structure had not been reported when examined under the SEM on the normal leech (Kua et al., 2009). The protruding proboscis could be due to the effect of exposure to $T$. indica and $M$. malabathricum plant extracts.
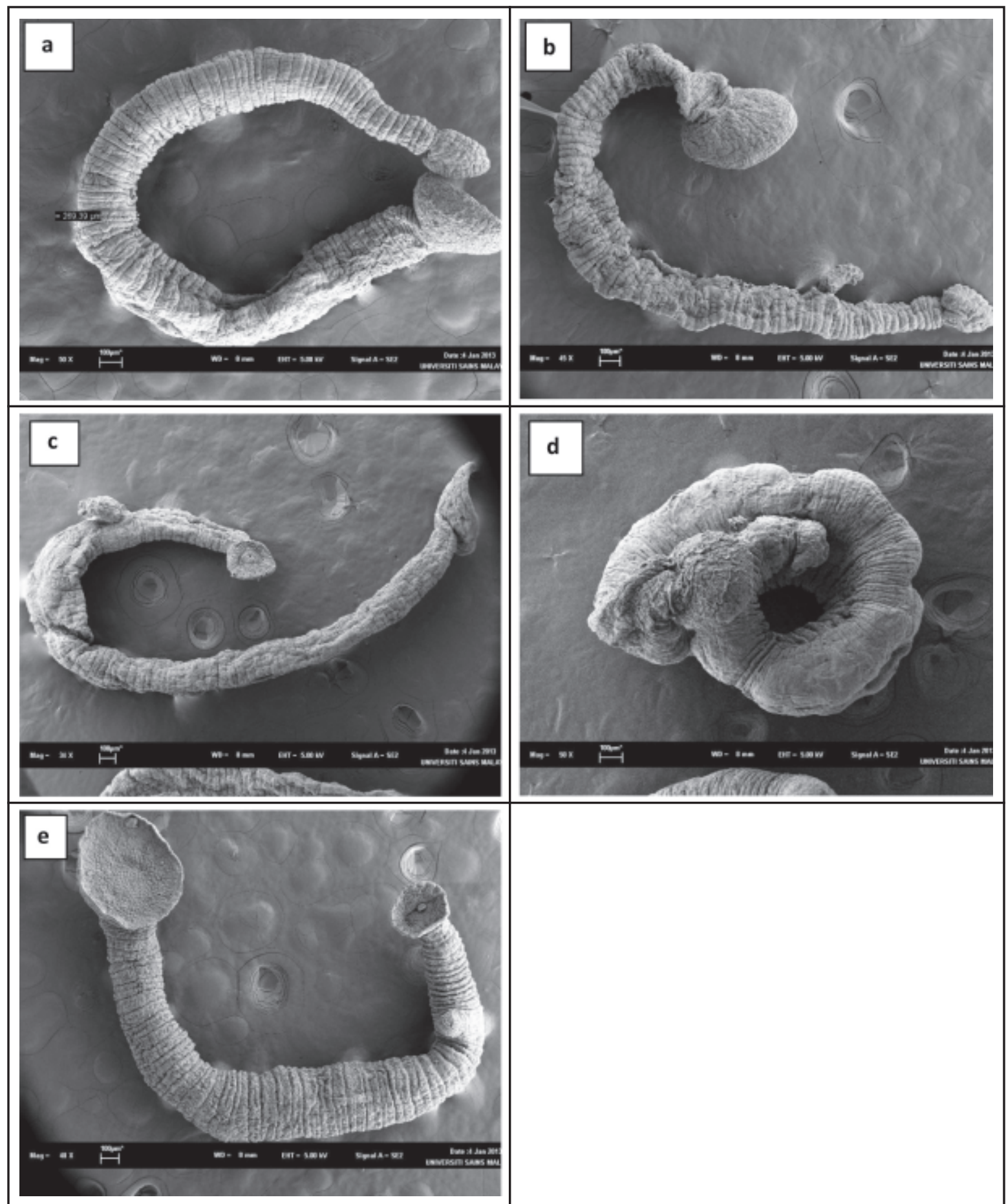

Figure 1. SEM Micrograph showing the gross morphology of marine leech (Z. arugamensis) after treatment (a) formalin treated leech; (b) Etlingera coccinea treated leech; (c) Tetracera indica treated leech; (d) Piper Betle treated leech; (e) Melastoma malabathricum treated leech. Scale bar, $1.2 \mathrm{~cm}=100 \mu \mathrm{m}$. 


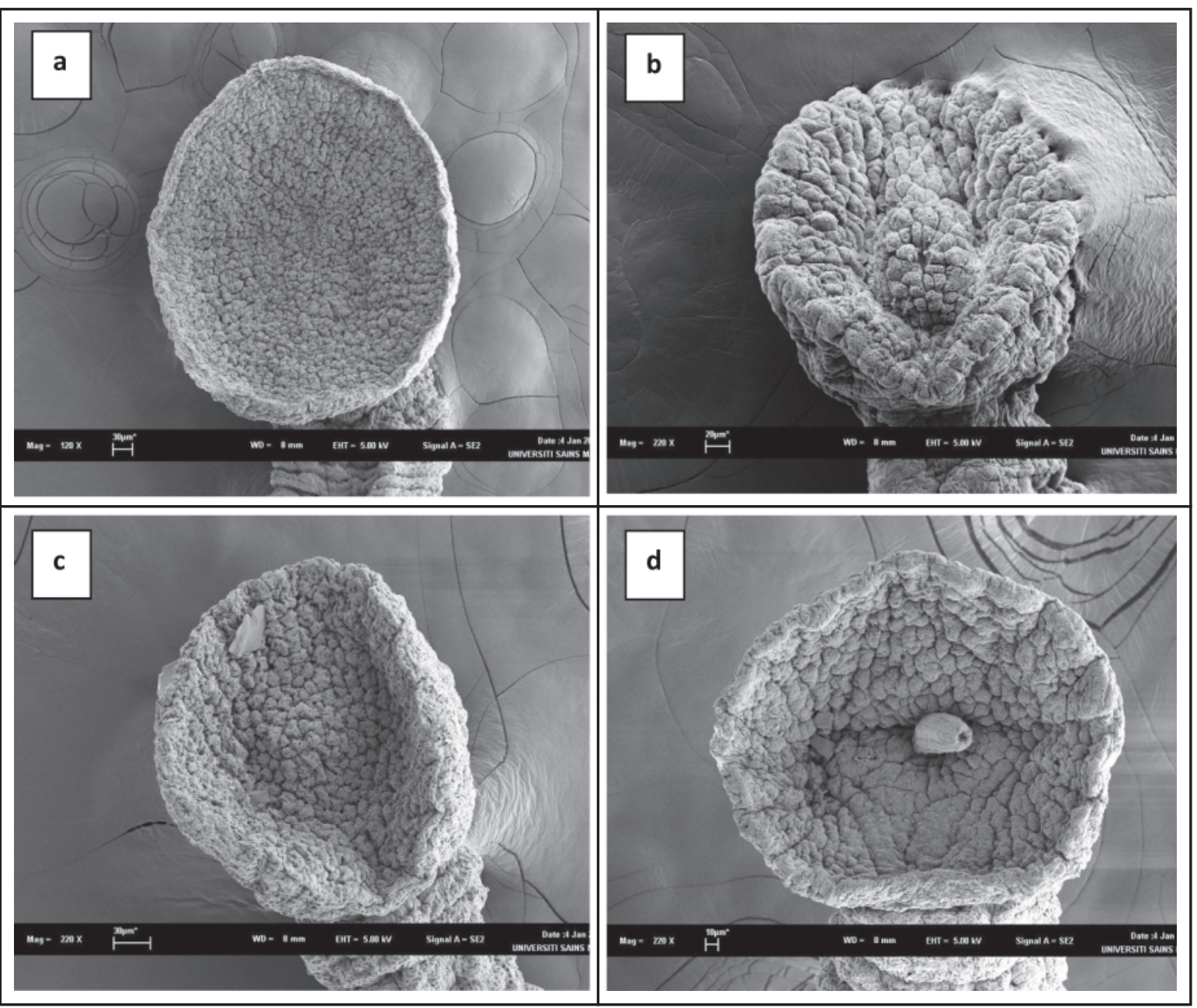

Figure 2. Different degrees of the protruded proboscis of the anterior sucker. SEM Micrograph showing the gross morphology of marine leech ( $Z$. arugamensis) after treatment (a) untreated leech; (b) Etlingera coccinea treated leech; (c) Tetracera indica treated leech; (d) Piper Betle treated leech; (e) Melastoma malabathricum treated leech. Scale bar, $1.2 \mathrm{~cm}=100 \mu \mathrm{m}$.

It is a well-known fact that plants produce various metabolites at different concentrations depending on the season, temperature and rainfall received during growth periods, including many other factors that require optimization if reproducible yields are to be obtained for commercial scale production. Thus, identifying and extracting pure active compounds is the best approach to achieve a controlled and consistently efficacious product at the industrial scale. However, this process could also disrupt useful interactions among components in crude extracts, some of which may enhance curative potency or bioavailability. So, inclusion of plant extracts as additives in feed could be another potential method of applying the findings from this study specifically to assist in the mitigation measures against marine leech infestation in small scale operations such as the marine fish hatcheries and aquarium.

This paper highlights our findings on the anti-marine leech (Z. arugamensis) activity of thirty-four (34) underutilized and commercial plant extracts in Malaysia. This study will be continued with the possible application of the extracts to the fish either orally, through immersion or by intraperitoneal injection. The next course of action will be the determination of the plants extracts toxicity to fish larvae and the identification of the phytochemical compound of the positive extracts.

\section{CONCLUSION}

The results of this study indicated that $M$. malabathricum, $T$. indica, $P$. betle, and $E$. coccinea aqueous extracts possess properties of anti-marine leech activity under laboratory conditions. Further experiments are warranted to determine the mechanisms behind this activity and toxicity effects. The rapid killing of adult leeches suggests that the four plant extracts could present a good potential to control marine leech infestation.

\section{Conflict of interest}

The authors declared that there is no conflict of interest.

\section{REFERENCES}

Ali, S.M. \& Mehta, R.K. (1970). Preliminary pharmacological and anthelmintic studies of the essential oil of Piper betle L. Indian Journal of Pharmacy 32: 132-133.

Bahmani, M., Avijgan, M., Hosseini, S.R. \& Qorbani, M. (2010). Evaluating the anti-Limnatis nilotica effects of tobacco methanol extract compared with succinyl choline and some other anti-parasite drugs. Shahrekord Journal of Medical Sciences 12(3): 53-59. 
Bahmani, M., Farkhondeh, T. \& Sadighara, P. (2012). The antiparasitic effects of Nicotina tabacum on leeches. Comparative Clinical Pathology, 21(3): 357-359. https://doi.org/ 10.1007/s00580-012-1413-x

Bahmani, M., Golshahi, H., Mohsenzadegan, A., Ghollami Ahangarani, M. \& Ghasemi, E. (2013). Comparative assessment of the anti-Limnatis nilotica activities of Zingiber officinale methanolic extract with levamisole. Comparative Clinical Pathology 22: 667-670. https://doi.org/ 10.1007/s00580-012-1463-0

Bahmani, M. \& Rafiean-Kopaei, M. (2014). Medicinal plants and secondary metabolites for leech control. Asian Pacific Journal of Tropical Disease 4(4): 315-316. https://doi.org/ 10.1016/S2222-1808(14)60580-6

Basripuzi, H.B., Sani, R.A., Ariff, O.M. \& Chandrawathani, P. (2013). Evaluation of enhanced virgin coconut oil and senduduk (Melastoma malabathricum) as anthelmintics against caprine strongyle nematodes. Tropical Biomedicine 30(3): 516-525.

Burreson, E.M. (1995). Phylum Annelida: Hirudinea as vectors and disease agents. In: Woo, P.T.K. Ed., Fish Diseases and Disorders: Vol. 1. Protozoan and Metazoan Infections. CAB International, UK, pp. 599-629.

Charles, S.V., Nagappan, T. \& Palaniveloo K. (2012). Essential oil composition, cytotoxic and antibacterial activities of five etlingera species from Borneo. Natural Product Communications 7(2): 239-242. https://doi.org/10.1177/ $1934578 \times 1200700233$

Cruz-Lacierda, E.R., Toledo, J.D., Tan-Fermin, J.D. \& Burreson, E.M. (2000). Marine leech Zeylanicobdella arugamensis infestation in cultured orange-spotted grouper Epinephelus coioides. Aquaculture 185(3-4): 191-196. https://doi.org/ 10.1016/S0044-8486(99)00356-7

Danquah, C.A., Koffuor, G.A., Annan, K. \& Ketor, E.C. (2012). The anti-helminthic activity of vernonia amygdalina (asteraceae) and alstonia Boonei de wild (apocynaceae). Journal of Medical and Biomedical Sciences 1(1): 21-27.

De Silva, P.H.D.H. (1963). Zeylanicobdella arugamensis gen. nov. and sp. nov. from Arugam Kalapu, Eastern Province, Ceylon. Spolia Zeylanica 30(1): 47-53.

De Silva, P.H.D.H. \& Fernando, C.H. (1965). Three marine leeches Piscicolidae, Hirudinea from the Malay Peninsula. Spolia Zeylanica 30: 227-232.

Dogarai, B.B.S. (2011). Phytochemicals and anti-diabetic activity investigation of Tetracera indica merr. Master's Thesis. International Islamic University Malaysia.

Garg, S.C. \& Jain, R. (1992). Biological activity of the essential oil of Piper betle L. Journal of Essential Oil Research 4(6): 601606. https://doi.org/10.1080/10412905.1992.9698142

Forouzan, S., Bahmani, M., Parsaei, P., Mohsenzadegan, A., Gholami Ahangaran, M., Sadeghi, E., Saki, K. \& Delirrad, M. (2012). Anti-parasitic activites of Zingiber officinale methanolic extract on Limnatis nilotica. Global Veterinaria 9(2):144-148.

Joffry, M.S., Yob, N.J., Rofiee, M.S., Affandi, M.M.R., Suhaili, Z., Othman, F., Akim, A.M, Desa, M.M. \& Zakaria, Z.A. (2012). Melastoma malabathricum (L.) Smith Ethnomedicinal Uses, Chemical Constituents, and Pharmacological Properties: A Review. Evidence-Based Complementary and Alternative Medicine. https://doi.org/10.1155/2012/258434

Leong, T.S. \& Wong, S.Y. (1988). A comparative study of the parasite fauna of wild and cultured grouper Epinephelus malabaricus Bloch et Schneider in Malaysia. Aquaculture 68(3): 203-207. https://doi.org/10.1016/00448486(88)90353-5
Kua, B.C., Burreson, E.M. \& Oo, M.G. (2009) Morphology of haematophagous marine leech (Zeylanicobdella arugamensis) isolated from sea bass (Lates calcarifer). Malaysian Fisheries Journal 8: 17-21.

Kua, B.C., Azmi, M.A. \& Hamid, N.K.A. (2010). Life cycle of the marine leech (Zeylanicobdella arugamensis) isolated from sea bass (Lates calcarifer) under laboratory conditions. Aquaculture 302: 153-157. https://doi.org/10.1016/j. aquaculture.2010.02.029

Kua, B.C., Choong, F.C. \& Leaw, Y.Y. (2014). Effect of salinity and temperature on marine leech, Zeylanicobdella arugamensis (De Silva) under laboratory conditions. Journal of Fish Disease 37(3): 201-207. https://doi.org/10.1111/jfd.12087

Shah, M.D., Venmathi Maran, B.A., Iqbal, M., Ching, F.F., Mohamad, Lal M.T., Binti Othman, R. \& Shapawi R. (2020). Antiparasitic activity of the medicinal plant Dillenia suffruticosa against the marine leech Zeylanicobdella arugamensis (Hirudinea) and its phytochemical composition. Aquaculture Research 51(1): 215-221. https:// doi.org/10.1111/are.14367

Pandey, A. \& Tripathy, S. (2014). Concept of standardization, extraction and pre-phytochemical screening strategies for herbal drug. Journal of Pharmacognosy and Phytochemistry 2(5): 115-119.

Patel, J., Kumar, G.S., Qureshi, M.S. \& Jena P.K. (2010). Antihelminthic activity of ethanolic extract of whole plant of Eupatorium odoratum. International Journal of Phytomedicine 2: 127-132.

Rahmani, M.B., Kiew, R.U.T.H., Lajis, N.H., Othman, R. \& Toia, R.F. (1985). A contribution to the phytochemical survey of Peninsular Malaysia. Pertanika 8(3): 347-357.

Raj, P.S., Babu, S.J. \& Gladstone, M. (1977). Anatomical details of two fish leeches from the Pulicat Lake, South India. Journal of the Marine Biological Association of India 19: 35-43.

Ravi, R. \& Yahaya, Z.S. (2017). Zeylanicobdella arugamensis, the marine leech from cultured crimson snapper (Lutjanus erythropterus), Jerejak Island, Penang, Malaysia. Asian Pacific Journal of Tropical Biomedicine 7(5): 473-477. https:// doi.org/10.1016/j.apjtb.2017.01.018

Simanjuntak, M. (2008). Ekstraksi and fraksinasi komponen ekstrak daun tumbuhan senduduk (Melastoma malabathricum) serta pengujian efek sediaan krim terhadap penyembuhan luka bakar, M.S. thesis, Universitas Sumatera Utara, Sumatera, Indonesia, (in Malay language) http://repository.usu.ac.id/bitstream/ 1234567-89/14472/1/09E01171.pdf

Sugumaran, M., Poornima, M., Venkatraman, S. \& Lakshmi, M. Srinivasansethuvani. (2011). Chemical composition and antimicrobial activity of sirugamani variety of Piper betle Linn Leaf oil. Journal of Pharmacy Research 14(10): 34243426.

Suteky, T. \& Dwadmadji, H. (2011). Anthelmintic activity of Melastoma malabathricum extract on Haemonchus contortus activity in vitro. Asian Journal of Pharmaceutical and Clinical Research 4(1): 68-70.

Zakaria, Z.A., Raden, M.N.R.N., Hanan Kumar, G., Abdul Ghani, Z.D., Sulaiman, M.R., Rathna Devi, G., Mat Jais, A.M., Somchit, M.N. \& Fatimah, C.A. (2006). Antinociceptive, antiinflammatory and antipyretic properties of Melastoma malabathricum leaves aqueous extract in experimental animals. Canadian Journal of Physiology and Pharmacology 84(12): 1291-1299. https://doi.org/10.1139/y06-083 